\title{
Resenha: \\ Memórias de um sobrevivente: o fato que cria o escritor e o escritor que recria os fatos
}

Tiago Lopes Schiffner ${ }^{1}$

Escrito durante os anos de aprisionamento de Luiz Alberto Mendes - Memórias de um sobrevivente não é apenas um relato realístico sobre a trajetória de um menino infrator e de um adolescente condenado. Embora geralmente se destaque a história de sofrimento e de pobreza do escritor paulista, como se fosse quase o roteiro de um documentário há em Memórias de um sobrevivente um esmero artístico que corrompe as balizes da despretensiosa exposição de um testemunho.

Indiscutivelmente, não se pode perder de vista o percurso do menino carente a menor infrator. E, por isso, é necessário refletir sobre a desigualdade social que ceifa inúmeras infâncias, cujos destinos são a atividade laboral precoce ou a criminalidade, por vezes, irremediável. Além disso, os exemplos dos atos de violência ensejados pelos educadores e policiais podem orientar a reflexão sobre o uso do poder pelas autoridades constituídas, seja dentro, seja fora das cadeias. No entanto, o romance autobiográfico de Mendes não se restringe a essas importantes questões e não seria o texto de alto valor literário que é, caso não encerrasse também um empenho estilístico do autor.

Crivada de diretas frases curtas, a cadência da narrativa se desmembra dos episódios que descreve. A constante oscilação de períodos breves e brevíssimos concentra no seu bojo o modo acelerado como o Luiz do passado se inscreve na vida. O olhar dele é rápido como a escrita, e os parágrafos se constituem de sucessivos comentários e descrições, os quais remontam as feições dos acontecimentos relembrados. Alterna-se o narrar de atos e o descrever de ambientes com dinamismo. Dessa maneira, o leitor acompanha os pequenos detalhes do movimento de um guarda à espreita, de um companheiro mal intencionado ou do olhar brejeiro e convidativo de uma mulher, numa linguagem célere.

Juntamente a essa habilidade de retratar, a nitidez do perfil psicológico destemido dos jovens e a reconstrução dos eventos de perigo aos quais estão sujeitos produzem zonas de tensão na narrativa criadas com maestria. A cada esquina do texto, espera-se uma reviravolta: a fuga, a captura ou o desfecho trágico. O que é reforçado por construções tais como - "a estratégia do assalto [...] parecia perfeita" (MENDES, 2009, p. 311), cuja imperfeição do tempo verbal antecipa a derrocada do plano dos, até então, assaltantes bem sucedidos. Outro exemplo é a passagem da chegada de Luiz à casa do amigo, Oscar - o qual não teme a arma empunhada pelo companheiro. Nesse momento, o narrador menciona: "se 


\section{Conexão Letras}

ele soubesse...". A impressão é a de que haverá o conflito de desenlace lamentável. Porém, o horizonte de expectativa não se concretiza, e a camaradagem entre os dois não é abalada. A frase rápida, a contínua variação do ângulo narrativo e o imprevisível desenrolar do relato parecem representar, então, a insegurança e a aflição do personagem central diante das incertezas do cotidiano de rapaz marginalizado.

Em Memórias de um sobrevivente, a intimidade entre os episódios remotos e o formato do texto presente é tamanha que a sua personalidade de menino é sucintamente definida pela palavra "quieto" entre dois pontos finais (MENDES, 2009, p. 9). É como se essas passagens curtas as quais povoam o livro configurassem o caminho da paulatina reclusão e do isolamento de Mendes ao longo da autobiografia. E a oração "um em cada cela" (MENDES, 2009, p. 364) poderia sintetizar a disjunção que caracteriza o afastamento da família, da sociedade e na prisão.

No decurso completo, Luiz se separa da sua família, pois não concorda com atitudes de seu pai; encontra-se e se desencontra dos companheiros, amigos e amores efêmeros ao longo de inúmeras prisões; e é separado do mundo, da "rua [que se torna] ficção, ilusão" (MENDES, 2009, p. 384), quando assume a autoria de certos crimes. Ainda, como se não bastasse, é isolado no próprio presídio - nas várias ocasiões nas quais é condenado a permanecer nas celas-fortes. Nesse sentido, o livro de Mendes não enaltece a história em detrimento de sua forma - pelo contrário - transfigura em estrutura narrativa a carga biográfica. Por esse motivo, a realidade rememorada é tão vital quanto a informação estilística que a assimila.

Nos "estreitos limites a que lhe coagem a gramática e a lei" (RAMOS, 1987, p. 8), Mendes conquistou a fluência textual numa sintaxe contida, como quando se sentia livre numa cela reduzida ao percorrer os romances de Dostoiévski, John Steinbeck, Górki, Erico Veríssimo, entre outros. E é nesses momentos de solidão que se apropria dessa outra cultura tão "marginal e secreta" quanto a produzida dentro do cárcere (MENDES, 2009, p. 153). Memórias de um sobrevivente é o "equilíbrio" entre a cultura humana e social - descoberta inicialmente nas conversas com Carlão e Henrique Moreno - e a do crime, assimilada durante a infância e a adolescência nos estabelecimentos de atendimento socioeducativo. É a conciliação aparentemente inconciliável de duas perspectivas de vida: uma livre e irreprimível e outra de clausura e fereza. Por isso, mesmo as cenas nas quais há a representação da crua brutalidade irrefreada, coexiste o lirismo cotidiano:

Tiram os panos. Protegeram a carne do cano, não deixaram marcas. A perfeição do torturador é causar o maior volume de dano e jamais deixar vestígios. Mandaram que me levantasse. Tentei. Não senti as pernas. Parecia um monte de roupas molhadas, moles. Da cintura para baixo, não existia. Assustei-me. Era como após as surras de meu pai, o alívio era tão grande que até dava uma espécie fina de prazer. Ficava a dor, mas era uma doce dor (MENDES, 2009, p. 63).

As pancadas de cassetete já findaram nesse excerto. Todavia, o fragmento ainda ecoa as reverberações de sons de baixa tonalidade, como se ressoassem os golpes surdos do ferro no corpo do menino. Nas palavras "pano, cano, dano", o efeito das consoantes plosivas no início dos vocábulos, o qual se propaga nas reiterações de vogais de timbre fechado e nasalizado, se assemelha demasiadamente à força reprimida do braço do soldado que se prolonga no bastão e explode com violência na "carne" da criança. O incipiente impulso de energia encontra a resistência passiva no correr dessas letras, igualmente ao que ocorre na cena da tortura. 
Na escolha de "monte, molhadas, moles", o intento expressivo parece distinto daquele do primeiro trio. Essa sequência é constituída de um quase ininterrupto fluxo sonoro de intensidade amena, produzido pelo encadeamento de vogais também de tom reduzido, nasais e laterais. A agressão inicial é mitigada nessas repetições, como o é na cena de tortura. E resta apenas a tentativa de recuperar a energia das pernas que estão em frangalhos após as sucessivas estouradas.

A implicação das escolhas lexicais fica ainda mais importante quando se percebe a retomada continua da palavra "dor". Ela aparece repetida por três vezes: duas de modo substantivado e outra por paridade fonética em “tortura-dor". Essas reiterações caracterizam o sentimento infligido pelo soldado no prisioneiro, cuja sensação relembra as surras do pai. Ainda, o uso de "torturador" - como modo de distinguir o militar que o espancava - enaltece o emprego do presente do indicativo com o sentido de situação imutável: "A perfeição do torturador é causar o maior volume de dano e jamais deixar vestígios” (...). Desse modo, o escritor demonstra de maneiras distintas que o agente da violência traz em si a sua causa.

Por fim, o eco da parte final e o emprego do verbo no passado imperfeito configuram a extinção paulatina do sofrimento do corpo, cuja marca nunca se apagará completamente do sujeito. Com a análise do excerto - uma pequena parcela significativa do todo das Memórias de um sobrevivente - é evidente que a composição narrativa não fica ilesa às recordações de Luiz. Pelo contrário, as frases e as características da construção dos períodos repercutem o representado e o vivido nesse romance autobiográfico. Assim, a arguta agilidade discursiva sintomática da dialética entre o anseio de liberdade e os limites da condição social empobrecida colada à repressão violenta aproximam algumas soluções estéticas de Luiz Alberto Mendes das realizadas por demais autores brasileiros - tais como: João Antônio, Rubem Fonseca e Luiz Ruffato.

Nos versos de Carlos Drummond de Andrade: "o medo, com sua física, tanto produz: carcereiros, escritores, esse poema; outras vidas" (ANDRADE, 2000, p. 27). No caso de Mendes, tanto o medo - "o instrumento mais utilizado e aproveitado naquela sucursal do inferno" (MENDES, 2009, p. 258) - quanto os demais sentimentos e fatos maléficos e benéficos ensejados num contexto autoritário e violento, no qual anseia uma ideia forte e vaga de liberdade difundida pelos insipientes meios de comunicação e incorporada pelos novos ídolos de calça Lee ou pelos malandros de revólver, constituem a hi(e)stória de Memórias de um sobrevivente. Contagiada por ela, a maneira de narrar - construída de numerosos recomeços: seja num único parágrafo, seja na passagem entre eles - e a sua linguagem, permeada de um lirismo cotidiano ferido pela violência, produzem um relato no qual conteúdo e forma ocupam o mesmo espaço.

\section{Referências}

ANDRADE, Carlos Drummond de. A Rosa do povo. $21^{\text {a }}$ ed. Rio de Janeiro: Record, 2000, $205 \mathrm{p}$.

MENDES, Luiz Alberto. Memórias de um sobrevivente. São Paulo: Companhia de Bolso, 2009, 416 p.

RAMOS, Graciliano. Memórias do cárcere. $9^{\mathrm{a}}$ ed. São Paulo: Círculo do Livro, 1987. 4 v. 